\title{
Sakarya Nehri Deltası'nda Uzun Süreli Rüzgar ve Dalga İklimi Değişimleri
}

\section{Long-term Wind and Wave Climate Variations in the Sakarya River Delta}

\section{Cihan Şahin ${ }^{*}$ (i)}

${ }^{1}$ Yıldız Teknik Üniversitesi İnşaat Fakültesi, İnşaat Mühendisliği Bölümü, İstanbul, TÜRKIYE Sorumlu Yazar / Corresponding Author*: cisahin@inm.yildiz.edu.tr

\author{
Geliş Tarihi / Received: 24.04.2019 Araştırma Makalesi/Research Article \\ Kabul Tarihi /Accepted: 30.12.2019 DOI: 10.21205/deufmd.2020226505 \\ Atıfsekli/How to cite:SAHIN, C.(2020). Sakarya Nehri Deltasın'nda Uzun Süreli Rüzgar ve Dalga İklimi Değişimleri. DEUFMD 22(65), 353-368.
}

Öz

İklim değişikliği ile ilgili küresel tahminler küresel ısınma, deniz suyu seviyesinde yükselme ve ekstrem iklimsel olaylarda artışı işaret etmektedir. İklim değiş̧ikliği sonucunda kıyılardaki değiş̧imde etkili temel değişkenler deniz suyu seviyesinde yükselme, dalga özellikleri, firtına sıklığı/şiddeti ve akarsu taşkınlarıdır. Delta düzlükleri yoğun nüfusa sahip bölgelerdir ve çok sayıda insan karasal (akarsu tașkınları gibi) ve/veya denizel (fırtına kabarmaları, erozyon) dıș etkenlerin etkisi altında kalmaktadır. Haliç ve deltalar, özellikle deniz seviyesi yükselmesi ve yağışlardaki değişimler gibi iklim değişikliği etkilerine karşı yüksek derecede kırılgan bölgeler olarak gösterilmektedirler. Bu çalıșmada, bir akarsu delta bölgesinde iklim değișikliğinin, rüzgar ve dalga iklimi üzerindeki etkilerinin değerlendirilmesi amaçlanmaktadır. Pilot bölge olarak Karadeniz kıyı kesimi içinde Karasu kıyısında yaklașık 80 km kıyı șeridine sahip kırılgan bir delta bölgesi olan Sakarya Nehri Deltası seçilmiştir. Çalışma bölgesine ait uzun süreli rüzgar ve dalga verisi NOAA CFSRR veri tabanından elde edilmiş ve bu veriler Karadeniz'de farklı konumlarda ölçülmüş veriler ile doğrulanmıştır. Yıllık ortalama değerler incelendiğinde rüzgar hızlarında ve belirgin dalga yüksekliklerinde uzun dönemde azalma (sırasıyla \%4 ve \%11) olduğu görülmüștür. En büyük rüzgar hızı ve belirgin dalga yüksekliğinde ise sırasıyla yaklaşık \%12 ve \%6 artış eğilimi olmaktadır. Fırtına şiddetlerinin yanında sıklığının da belirgin bir șekilde arttığı (ortalama \%100'e varan artış) görülmektedir. Bu çalışma sonucunda, bölgenin rüzgar ve dalga iklimindeki uzun dönemli değişimlerin iklim değişikliği göstergeleri ile büyük ölçüde uyum gösterdiği belirlenmiștir.

Anahtar Kelimeler: İklim değişikliği, Dalga iklimi, Rüzgar iklimi, Sakarya Nehri, Akarsu deltası

\section{Abstract}

Global projections on the concept of climate change mainly indicate global warming, sea level rise and increases in climatic extremes. The main drivers of coast evolution related to climate change are rising sea levels, wave characteristics, storm frequency/intensity, and river floods. Delta plains are densely populated, and large numbers of people are often impacted by external terrestrial influences (e.g., river floods) and/or external marine influences (storm surges, erosion). Estuaries and deltas are widely recognized as highly vulnerable to the impacts of climate change, particularly sea-level rise and changes in runoff. The goal of this study is to evaluate the impact of climate change on wind and wave climate in a deltaic area. Sakarya River Delta system, a vulnerable deltaic area with a shoreline 
stretching approximately $80 \mathrm{~km}$ in Karasu province on the Black Sea coast of Turkey, is selected as a case study. Long-term wind and wave data in the study area were obtained from the NOAA CFSRR database and validated with measurements at different locations over the Black Sea. Annual mean wind speed and significant wave height show long-term decreasing trends $(\sim 4 \%$ and $\sim 11 \%$, respectively). Maximum wind speed and significant wave height tend to increase by $12 \%$ and $6 \%$, respectively. In addition to the storm intensities, storm frequency also increases significantly (up to a $100 \%$ increase). The results of this study indicate that long-term changes in wind and wave climate in the study area are broadly consistent with climate change indicators.

Keywords: Climate change, Wave climate, Wind climate, Sakarya River, River delta

\section{Giriş}

İklim değişikliği ile ilgili küresel göstergeler genel olarak küresel ısınma, deniz suyu seviyesinde yükselme ve ekstrem olaylarda artışı işaret etmektedir [1-4]. Dünya'daki kıyıların \%70'inden fazlasında son 30 yıldır deniz yüzeyi sıcaklıklarında belirgin artışlar gözlenmektedir. Artış miktarları yüksek konumsal ve mevsimsel değişimler göstermekle birlikte, on yıllık ortalama sıcaklık değișimi 0.18 $\pm 0.16^{\circ} \mathrm{C}$, on yılda mevsim zamanlarındaki ortalama değișim ise $-3.3 \pm 4.4$ gün olarak verilmiștir [5]. Kıyı sistemlerinin, artan su seviyesi, artan sıcaklıklar, yağışlardaki değişim, daha büyük fırtına kabarmaları ve asit yağışlarındaki artıştan büyük ölçüde etkilenmesi beklenmektedir [6]. 2100 yllında iklim değişikliği kaynaklı küresel su seviyesi artışının etkisinin $0.28 \mathrm{~m}$ ila $0.98 \mathrm{~m}$ düzeyinde olacağ öngörülmektedir [7]. Bölgesel değișimler ve yerel etkenler sonucunda yerel su seviyelerinde bu değerlerden daha fazla yükselme gözlenmesi olasıdır [6]. Deniz seviyesi yükselmesinin en önemli etkileri artan kıyı taşkınları, artan kıyı erozyonu ile haliç ve deltalara tuzlu su giriși olarak sıralanmaktadır [8]. 100 yıllık yinelenme periyoduna sahip belirgin dalga yüksekliğinin ise $\% 20$ ile $\% 40$ arasında artacağ edilmektedir [9]. Dolayısıyla, iklim değișikliğinin kıyı kentleri, deltalar ve düşük rakımlı bölgelerde ciddi etkilerinin olması beklenmektedir.

Dalga özellikleri, fırtına sıklığı/ şiddeti ve kıyı geri çekilme miktarı iklim değişikliği ile ilgili olarak kıyılarda morfolojik değişimin ana etkenleridir [7]. Kısa zaman ölçeğinde, şiddetli fırtına kabarmaları, dalga aşması gibi nedenlerden dolayı kıyı taşkınları ve kıyı erozyonu gibi etkiler meydana gelmektedir. Uzun zaman ölçeğinde ise rüzgar ve dalga iklimindeki değişiklikler kıyılarda katı madde taşınımında ve devamında erozyon ve birikmelerde değişikliklere neden olmaktadır. Tatlı su girdisindeki değişimler ise denizlerdeki tuzluluk konsantrasyonunda değişime neden olmaktadır [6].

Küçük deniz tabanı eğime sahip düşük rakımlı bölgeler olan haliç ve deltalar, iklim değișikliğinin bir sonucu olarak gelecekte görülebilecek su seviyesi yükselmelerine karşı yüksek derecede kırılgan bölgeler olarak sınıflandırılmışlardır [10]. Bu bölgeler, nehir, kara ve okyanusun etkileșimde olduğu yerlerdir ve nehir, gel-git, dalga ve akıntı süreçlerinin birleşiminden etkilenmektedir. Deltalar, çok çeşitli habitata sahip doğal sistemlerin (gel-git düzlükleri, tuzlu bataklıklar, su basan ormanları, kumsallar, haliçler, düşük rakımlı kıyı alanları gibi) ve insan yaşamının (evler, tarım, su ürünleri yetiştirme alanları, endüstri ve tașımacılık gibi) bir araya geldiği yoğun insan nüfusuna sahip bölgelerdir. Özellikle son 60008000 ylldaki görece az değişken seviyesiyle birlikte nehir ağızlarında biriken katı maddelerin oluşturduğu düşük rakımlı kıyı oluşumlarıdır ve dünya ortalamasının 10 katından daha fazla nüfus yoğunluğuna sahip bölgelerdir [11-12]. Deltalar, kendi içlerindeki iklimsel etkilerin yanında akarsuların memba bölgelerinden (tatlı su giriși gibi) ve okyanusların mansaplarından (su seviyesi değişimleri, dalgalar gibi) gelen iklimsel etkilere de maruz kalmaktadırlar. Yükselen su seviyesinin etkisi, değișen fırtına sıklığı ve biçimi ile birleştiğinde, geçici olarak belirgin kıyı erozyonu ve tașkınlarına neden olması olasıdır [13].

Katı madde debisinde azalma, deniz seviyesi yükselmesi, delta ve nehirlerdeki arazi kullanımında değişimler gibi etkilerin birleşimi, deltalarda büyük ölçüde erozyona yol açmaktadır. Barajlar, sulama yapıları, seddeler 
ve duvarlardan kaynaklanan nehir katı madde deşarjlarındaki değișimler, kıyı alanlarındaki katı madde bütçesinde dengesizliğe neden olmaktadır. Çok sayıda delta bölgesi için kıyılarda, su basan orman alanlarında, gel-git düzlüklerinde ve deltaların su altında kalan kısımlarında gerilemenin olduğu rapor edilmiştir (örneğin, Nil ve Ebro Deltaları [14], Po Deltası [15], Krishna-Godavari Deltası, [16], Changjiang Deltası, [17], Huang He Deltası, [18]). Delta kıyıları, kıyı çizgisinin denize doğru ilerlemesi sonucunda genişlemekte ve bunun sonucunda delta düzlükleri oluşmaktadır. Ancak, son 50 yılda azalan katı madde debileri sonucunda delta kıyılarının gelişimi yavaşlamakta, bazı bölgelerde süreç tersine dönmektedir (Nil, Godavari, Huanghe deltaları gibi, [6]). İklimsel etkenler, meydana gelen bazı meteorolojik olayların etkilerini de arttırmakta ve toprak kaybını hızlandırmaktadır (örneğin, 2005 yılındaki Katrina ve Rita kasırgaları, [19]). Su baskınlarını ve taşkınları engellemek için, deltalara kurulan çok sayıda kentin taşkın koruması ve su kaynakları yönetimi için önemli altyapı geliştirilmektedir [7]. Dünya genelinde 33 delta için yapılan çalışmalar, geçtiğimiz on yılda bu deltaların \%85'inin şiddetli taşkınlara maruz kaldığını ve $260,000 \mathrm{~m}^{2}$ alanın geçici olarak sular altında kaldığını göstermektedir [20]. Hükümetler arası iklim değișikliği paneli [2] tarafından öngörülen deniz seviyesindeki artış tahminlerine göre, 2100 yılında bu deltalardaki taşkın alanlarının \%50 artacağı öngörülmektedir [20]. Bu etkilerin yanında nüfus artıșı da düșünüldüğünde, yoğun nüfuslu deltaların daha kırılgan olduğu düşünülmektedir. 2100 yılı sonrasında, deltaların daha karmaşık ve artan etkilere maruz kalacağı tahmin edilmektedir [21].

$\mathrm{Bu}$ çalışmada, kırılgan bölge olarak tanımlanan bir akarsu delta sisteminde rüzgar ve dalga ikliminin uzun süreli değișimi incelenerek olası iklim değişikliği etkileri araştırılacaktır. Çalışma bölgesi olarak Karadeniz kıyı kesimi içinde Karasu kıyısında bulunan Sakarya Nehri Deltası seçilmiştir. Çalıșma bölgesi, makalenin ikinci bölümünde ayrıntılı olarak tanımlanmıș ve önemi belirtilmiştir. Üçüncü ve dördüncü bölümlerde sırasıyla bölgenin uzun dönemli rüzgar ve dalga iklimleri detaylı bir şekilde incelenerek olası iklim değişikliği etkileri ile ilgili bulgulara yer verilmiştir. Bu çalışmadan elde edilen sonuçlar son bölüm olan beșinci bölümde değerlendirilmiștir.

\section{Materyal ve Metot 2.1. Çalışma bölgesi}

Ülkemizde Karadeniz kıyı kesimi içinde Sakarya ili'nin Karasu kıyısında yer alan Sakarya Nehri Deltası iklim değişikliği etkilerine karşı olası kırılgan bölgelere iyi bir örnektir. Döküldügü Karadeniz'de kıyı kesimini oluşturan Sakarya Nehri, İç Anadolu'ya kadar uzanan besleme havzasına sahiptir. Sakarya Nehri Havzası Türkiye'nin 26 büyük akarsu havzasından birisidir [22]. Drenaj alanı $58.160 \mathrm{~km}^{2}$ olan Sakarya havzası, Türkiye yüzölçümünün \%7,46'sı büyüklüğündedir [23]. Sakarya Nehri'nin kolları ile birlikte toplam uzunluğu 824 km'dir. Sakarya Deltası, denize doğru hafifçe uzayan bir şişkinlik yaparak doğu-batı yönünde 25 km uzanmaktadır. Doğu ve batı yönünde daralarak alanı yaklaşı $70 \mathrm{~km}^{2}$ olmaktadır. Sakarya Nehri'nin taşıdığı yıllık ortalama askıda

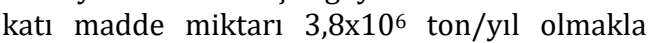
birlikte, bu değer nehrin üst bölümünde Gökçekaya Barajı'nın 1972 yılında yapımından sonra daha önceki değer olan 4,6×106 ton/yll değerine göre azalmıştır [24].

Bölgedeki dalga yapısı, kıyı alanında önemli ölçüde kıyıya dik kum taşınımına neden olmaktadır. Ayrıca, bölge hem doğudan batıya hem de batıdan doğuya katı madde taşınımının etkili olduğu kıyı boyu taşınımı açısından da aktif bir kıyı özelliğine sahiptir. Bu durum, Sakarya Nehri ağzında oluşan kum birikimlerinden ve kıyının morfolojik yapısından da anlaşılmaktadır. Sakarya Nehri'nin Karadeniz'e taşıdığı kum, dalga ve akıntı yapısının da etkisiyle akarsu ağzının ve komșu kıyıların morfolojik yapısını șekillendirmektedir (Şekil 1). $\mathrm{Bu}$ yapı, çok geniş plaj alanlarının oluşması ve plaj gerisinde genç kumullardan fosilleşmiş kumullara doğru binlerce yılda oluşmuş kumsal görünüm ile doğrulanmaktadır [24].

Sakarya Nehri ağzının batı kıyısında 1,5 km içeride ve kıyıya paralel olarak uzunlamasına 12 $\mathrm{km}$ devam eden, derinliği 1,5 metre ve yaklaşık alanı 1.560 hektar olan, açı su, deniz, nehir ve kıyı kumullarını bir arada barındıran, saz, kamış, su bitkileri ve çiçekleri ile dişbudak, kızılağaç, karaağaç, söğüt ağaçları ile kaplı, Dünya'nın tek parça halindeki en büyük longozu olma özelliğine sahip Acarlar Gölü ve su basan ormanı yer almaktadır [24]. Acarlar su basan ormanı, yılda 200'e yakın kuş türüne ev sahipliği yapmaktadır. Bütün bu özellikleri bir arada 
barındırması sebebiyle Longoz (Su basan ormanı) olarak tanımlanmaktadır ve 1 . Derecede Doğal Sit Alanı olarak koruma altına alınmıștır. Dișbudak ormanlarıyla kaplı bu göl, kıyının gerisinde uzanan kumul setlerinin arkasındaki çukur alanın sularla kaplanması sonucunda oluşmuștur. Karasu kıyı alanı, sahip olduğu nadir doğal yapısının yanı sıra bu yapısı ile gerisindeki Acarlar Longozunu da denizin așındırıcı etkisinden korumaktadır [24, 25].
Sakarya Nehri Havzası'nda yer alan illerde yașayan nüfus ve yürütülen faaliyetler Sakarya Nehri'ni ve akarsuyun oluşturduğu kıyı kesimini doğrudan etkilemektedir. Ancak bu etki, havzanın Karadeniz ile buluștuğu nokta olan Sakarya ili Karasu kesiminde kümülatif olarak yansımaktadır. Sakarya havzasında uzun yıllardır içme suyu, sulama, taşkın önleme, enerji üretimi gibi amaçlarla baraj, tașkın önleme, sulama, katı madde kontrolü gibi su yapıları inşa edilmektedir [25].

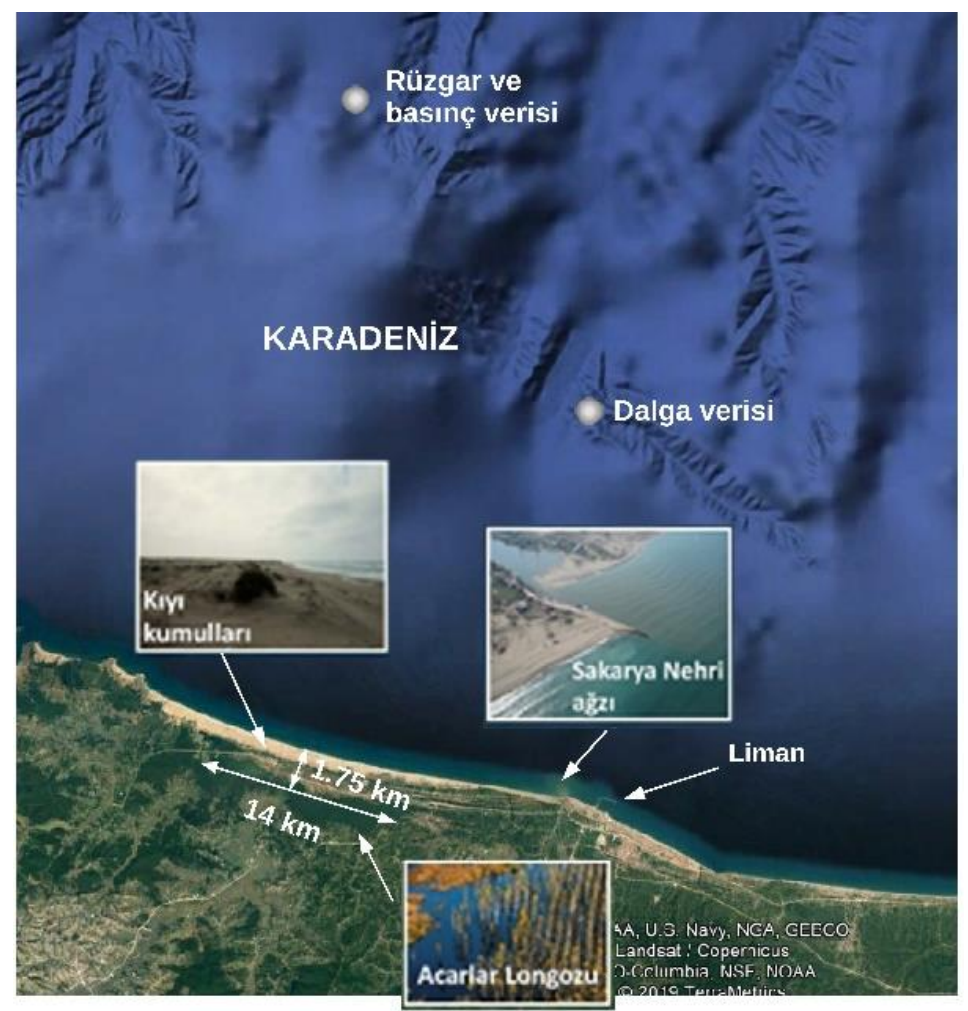

Şekil 1. Sakarya Nehri Deltası ve çevresindeki önemli kıyı alanları ve bu çalışmada kullanılan veriler

Akarsu debisinin barajların inșasından sonra ortalama \% 40 oranında azaldığı belirlenmiștir (Sekil 2). 1965 ve 2003 yıllarında yapılan nehir en kesiti ölçümleri karşılaştırıldığında, nehir yatağında genişleme ve 7 m'ye kadar oyulma olduğu tespit edilmiştir. Nehir ağız kısmında yığılmalar meydana gelirken, mansaba doğru oyulmaların artarak devam ettiği belirlenmiștir. Kıyıdaki geri çekilme miktarı yılda 7,5 m olarak ölçülmüştür [25].

Enerjik bir dalga-akıntı iklimine sahip, morfolojik açıdan dinamik, insan kaynaklı değișimlerin (nehir yatağında baraj inșaları ve kum alımı gibi) kıyı kesimini önemli ölçüde etkilediği, ekolojik, turistik ve ticari açıdan önemli alanları etki bölgesi içinde barındıran Sakarya Nehri Deltası, tüm bu özellikleriyle küresel iklim değişikliği sonucunda oluşması beklenen ekstrem olayların büyüklüğündeki ve sıklığındaki artış, deniz suyu seviyesinde yükselme ve nehir debisindeki değişim gibi süreçlerin etkisi altında kalması muhtemel bir bölgedir. Burada, uzun dönemli rüzgar, atmosfer basıncl ve dalga iklimindeki değişimler incelenerek bu etkilerin önemi araştırılacaktır. 
DEÜ FMD 22(65), 353-368, 2020

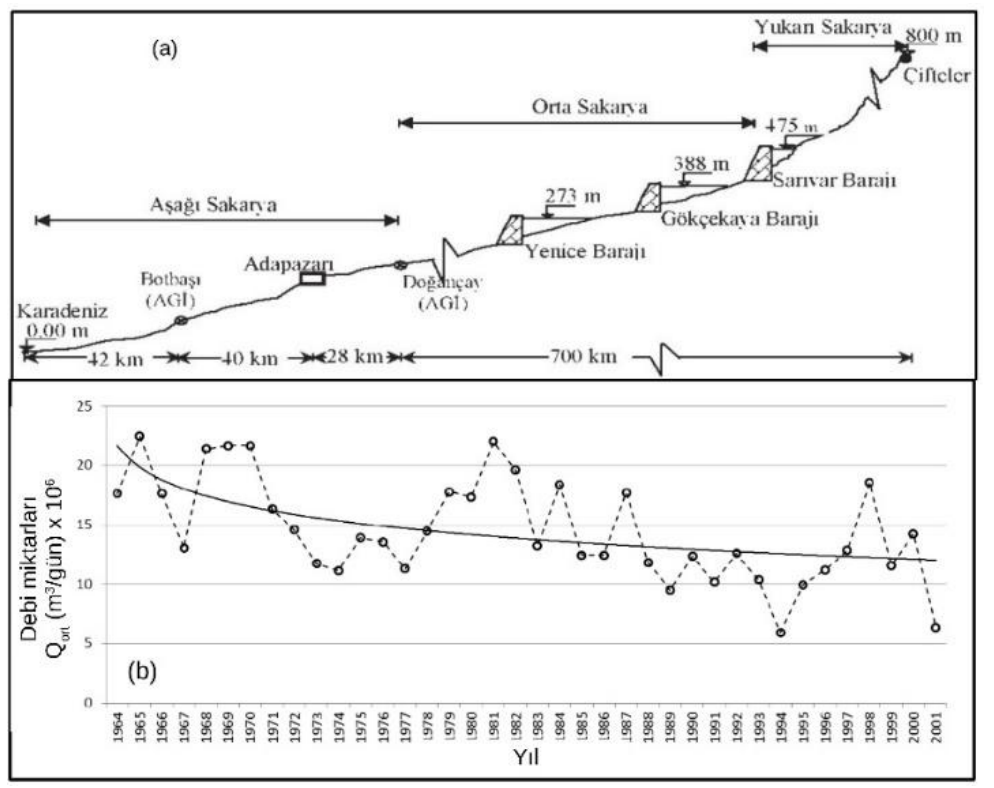

Şekil 2. (a) Sakarya Nehri boykesiti (ölçeksiz) ve barajların konumu. (b) Yıllara göre akarsu debisinin değişimi [25]

\subsection{Rüzgar ve basınç verisi}

$\mathrm{Bu}$ çalışmada kullanılan rüzgar ve atmosferik basınç alan verileri NOAA (National Oceanic Atmospheric Administration) tarafindan kullanıma açık olarak sunulan CFS (Climate Forecast System) veri tabanından elde edilmiștir [26]. CFS veri tabanında Ocak 1979 tarihinden Mart 2011 tarihlerine kadar olan veri tahminleri CFSR (CFS Reanalysis) olarak yer almaktadır. Mart 2011 tarihinde CFSR'nin ikinci sürümü faaliyete geçirilerek CFSv2 (CFSR 2. sürüm) sistemi ile Nisan 2011'den günümüze kadar uzatılmıştır.

Çalışma bölgesinin rüzgar ve basınç iklimindeki uzun dönemli değişimlerin araştırılması amacıyla 1979 ile 2017 yılları arasında Karasu'nun yaklaşık $40 \mathrm{~km}$ açığında, 41,50 Kuzey Enlemi ve $30,50^{\circ}$ Doğu Boylamı koordinatlarında 1 saat zamansal çözünürlüklü deniz seviyesinden $10 \mathrm{~m}$ yükseklikte tanımlanmış rüzgar hızı, yönü ve basınç verileri kullanılmıştır. Veriler üzerinde karasal faktörlerin etkisinin olmaması için klyıdan yaklaşık $40 \mathrm{~km}$ açıktaki veriler kullanılmıştır (Şekil 1).

\subsection{Dalga verisi}

Bu çalışmada kullanılan dalga verileri NOAA'ya bağlı NCEP (National Centers for Environmental
Prediction) tarafından geliștirilen iklim tahmin sistemi CFSRR (Climate Forecast System Reanalysis Reforecast) veri tabanından elde edilmiștir [27]. Bu veri tabanında, küresel ölçekte 1979 ile 2009 yılları arasını kapsayan 31 yıllık dalga iklimi bir üçüncü nesil rüzgar dalgası modeli olan WaveWatch III spektral modeli kullanılarak olușturulmuștur [28]. Dalga modelinde rüzgar girdisi olarak ortalama deniz seviyesinden $10 \mathrm{~m}$ yükseklikte tanımlanmıș, 1 saat zamansal çözünürlüğe ve tüm dünya üzerinde $90^{\circ} S^{\prime}$ dan $90^{\circ} \mathrm{N}$ 'a kadar $1 / 2$ derece konumsal çözünürlüğe sahip CFSR rüzgar verileri kullanılmıștır. Modelin doğrulanması Haziran-Aralık 2005 tarihleri arasını kapsayan Amerika Birleşik Devletleri'nin güneydoğu, kuzeydoğu ve batı kıyıları, Karayip Denizi, Meksika Körfezi, Kanada ve Hawaii kıyılarında bulunan çok sayıda şamandıra verisi ve altimetre verileri kullanılarak yapılmıștır. Sayısal dalga modelinden elde edilen çıktı parametreleri (belirgin dalga yüksekliği, ortalama dalga periyodu ve ortalama dalga yönü) 3 saat zamansal çözünürlükle NOAA tarafindan kullanıma açık olarak sağlanmaktadır.

NOAA'ya ait WaveWatch III spektral modeli verilerinin Türkiye kıyılarında doğruluğu ise çalışılmamıştır. Türkiye kıyılarındaki denizler kapalı denizlerdir ve bir modelin dünyanın farklı 
DEÜ FMD 22(65), 353-368, 2020

yerlerinde doğruluğunun gösterilmesi, Türkiye kıyılarında da doğru sonuçlar vereceği anlamını taşımamaktadır. Bundan dolayı, model sonuçları Karadeniz'in Karaburun (güneybatı Karadeniz) [29], Zonguldak Filyos [30], Sinop ve Hopa [31] kıyılarında mevcut dalga ölçümleri ile karşılaștırılarak, verilerin çalıșma bölgesinin de bulunduğu Karadeniz'deki doğruluğu incelenmiștir. Tablo 1'de doğrulama için kullanılan ölçüm istasyonlarının konumları ve ölçümlerin yapıldığı su derinlileri özetlenmiştir. Karşılaştırmalarda kullanılan ölçüm konumlarına ait model sonuçları, bu noktalara en yakın model sonuç noktalarındaki veriler arasında lineer interpolasyon yapılarak elde edilmiştir.

Tablo 1. Dalga ölçüm istasyonlarının coğrafi konumları ve su derinlileri

\begin{tabular}{cccc}
\hline İstasyon & $\begin{array}{c}\text { Enlem } \\
\text { (Kuzey) }\end{array}$ & $\begin{array}{c}\text { Boylam } \\
\text { (Doğu) }\end{array}$ & $\begin{array}{c}\text { Derinlik } \\
(\mathrm{m})\end{array}$ \\
\hline Karaburun & $41^{\circ} 21^{\prime} 0.869^{\prime \prime}$ & $28^{\circ} 41^{\prime} 27^{\prime \prime}$ & 16 \\
Filyos & $41^{\circ} 35^{\prime} 41^{\prime \prime}$ & $32^{\circ} 03^{\prime} 29^{\prime \prime}$ & 12,5 \\
Hopa & $41^{\circ} 25^{\prime} 24^{\prime \prime}$ & $41^{\circ} 23^{\prime} 00^{\prime \prime}$ & 100 \\
Sinop & $42^{\circ} 07^{\prime} 24^{\prime \prime}$ & $35^{\circ} 05^{\prime} 12^{\prime \prime}$ & 100 \\
\hline
\end{tabular}

Tablo 1'de verilen istasyonlarda farklı sürelerle ölçülmüş veriler mevcuttur. Örneğin, Karaburun'da Ağustos 2003 - Mart 2005, Filyos'ta Aralık 1994 - Aralık 1996, Hopa'da Aralık 1994 - Nisan 1999, Sinop'ta Kasım 1994 Haziran 1996 tarihleri arasında farklı zamansal çözünürlüklere sahip ölçüm verileri mevcuttur. Sayısal model verilerin doğruluğunun incelenmesi için mevcut olan tüm dalga ölçümleri ile karşılaştırılmalar yapılmıştır. Ortalama karesel hata (RMSE), ortalama hata (Bias), saçılım indeksi (Scatter Index, $S I$ ) ve korelasyon katsayısı $(R)$ gibi çeşitli istatistiksel hata parametreleri kullanılarak dalga modelinin performansı incelenmiştir. $\mathrm{Bu}$ parametreler aşağıdaki gibi hesaplanmaktadır:

$$
\begin{aligned}
& R M S E=\sqrt{\frac{1}{N} \sum_{i=1}^{N}\left(M_{i}-O_{i}\right)^{2}} \\
& \text { Bias }=\frac{1}{N} \sum_{i=1}^{N}\left(M_{i}-O_{i}\right) \\
& S I=\frac{R M S E}{\bar{O}}
\end{aligned}
$$

$R=\frac{\sum_{i=1}^{N}\left[\left(M_{i}-\bar{M}\right)\left(O_{i}-\bar{O}\right)\right]}{\sqrt{\sum_{i=1}^{N}\left(M_{i}-\bar{M}\right)^{2} \sum_{i=1}^{N}\left(O_{i}-\bar{O}\right)^{2}}}$.

Bu ifadelerde $N$ veri sayısını, $O_{i}$ ölçülen dalga parametresini, $M_{i}$ model sonucunu, $\bar{O}$ ölçüm verilerinin ortalamasını ve $\bar{M}$ model verilerinin ortalamasını göstermektedir.

Şekil 3'te farklı ölçüm istasyonlarına ait modellenen ve ölçülen belirgin dalga yükseklikleri zaman serilerinin karşılaştırılması için örnekler görülmektedir. Tüm istasyonlardaki karşılaştırmalarda elde edilen yüksek korelasyon katsayıları $(R)$ ve düşük hata değerleri, modellenen dalga yüksekliği verilerinin Karadeniz için yüksek doğruluğa sahip olduğunu göstermektedir (Tablo 2).

Şekil 4'te modellenen ve ölçülen ortalama dalga periyodu ve yönü zaman serilerinin karşılaştırılmasına örnek olarak Karaburun ölçüm istasyonuna ait bir yıllık karşılaştırılmalar görülmektedir. Bu grafikler hem dalga periyodu hem de dalga yönü için model sonuçları ile ölçüm verileri arasında iyi bir uyum olduğunu göstermektedir. Dalga yüksekliği tahminlerinde olduğu gibi dalga periyodu için de yüksek korelasyon katsayıları $(R)$ ve düşük hata değerleri elde edilmiştir (Tablo 3).

Tüm istasyonlardaki karşılaștırmalarda elde edilen sonuçlar (Şekil 3 ve 4 , Tablo 2 ve 3), NOAA'nın WaveWatch III spektral modeline ait dalga parametrelerinin Karadeniz'de uzun dönemli dalga iklimi çalışmasında kullanılabileceğini göstermektedir.

Çalışma bölgesinin dalga iklimindeki uzun dönemli değișimlerin araştırılması amacıyla 1979 ile 2009 yılları arasında Karasu'nun yaklaşık $23 \mathrm{~km}$ açığında, 41,3333 Kuzey Enlemi ve 30,6667 o Doğu Boylamı koordinatlarında 3 saat zamansal çözünürlüklü belirgin dalga yüksekliği, ortalama dalga periyodu ve yönü verileri kullanılmıştır (Şekil 1). Kıyıdan $23 \mathrm{~km}$ açıktaki verilen kullanılmasının nedeni dalgaların sığ sudaki batimetri etkilerinden dolayı değişime uğramadan analiz edilmesinin sağlanmasıdır. Dalga verisinin kullanıldığı nokta rüzgar verisi noktasının yaklaşı $20 \mathrm{~km}$ güneydoğusunda yer almaktadır. 
DEÜ FMD 22(65), 353-368, 2020
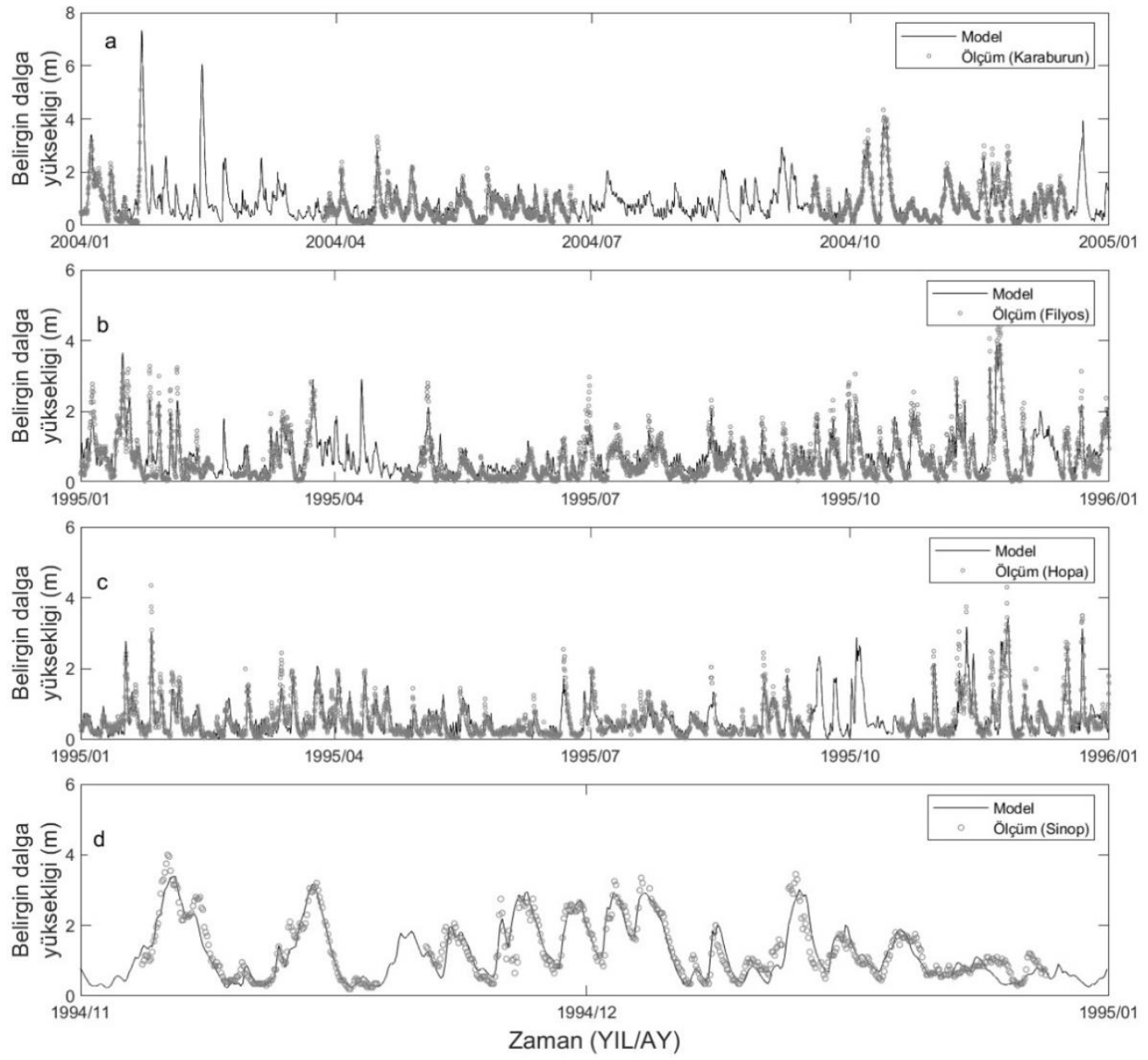

Şekil 3. Karadeniz'de farklı ölçüm istasyonları için WaveWatch III sayısal model sonuçları ile ölçülen belirgin dalga yüksekliği zaman serilerinin karşılaştırılması

Tablo 2. Farklı istasyonlar için ölçülen ve modellenen belirgin dalga yüksekliklerinin karșılaștırılması Belirgin dalga yüksekliği

\begin{tabular}{lcccccc}
\hline İstasyon & $\begin{array}{c}\text { Ölçüm ortalama } \\
(\mathrm{m})\end{array}$ & $\begin{array}{c}\text { Model ortalama } \\
(\mathrm{m})\end{array}$ & $R$ & RMSE $(\mathrm{m})$ & Bias $(\mathrm{m})$ & $S I$ \\
\hline Karaburun & 0,74 & 0,84 & 0,94 & 0,21 & 0,09 & 0,29 \\
Filyos & 0,62 & 0,71 & 0,90 & 0,24 & 0,08 & 0,38 \\
Hopa & 0,56 & 0,55 & 0,86 & 0,25 & $-0,02$ & 0,44 \\
Sinop & 0,92 & 0,88 & 0,91 & 0,29 & $-0,06$ & 0,32 \\
\hline
\end{tabular}



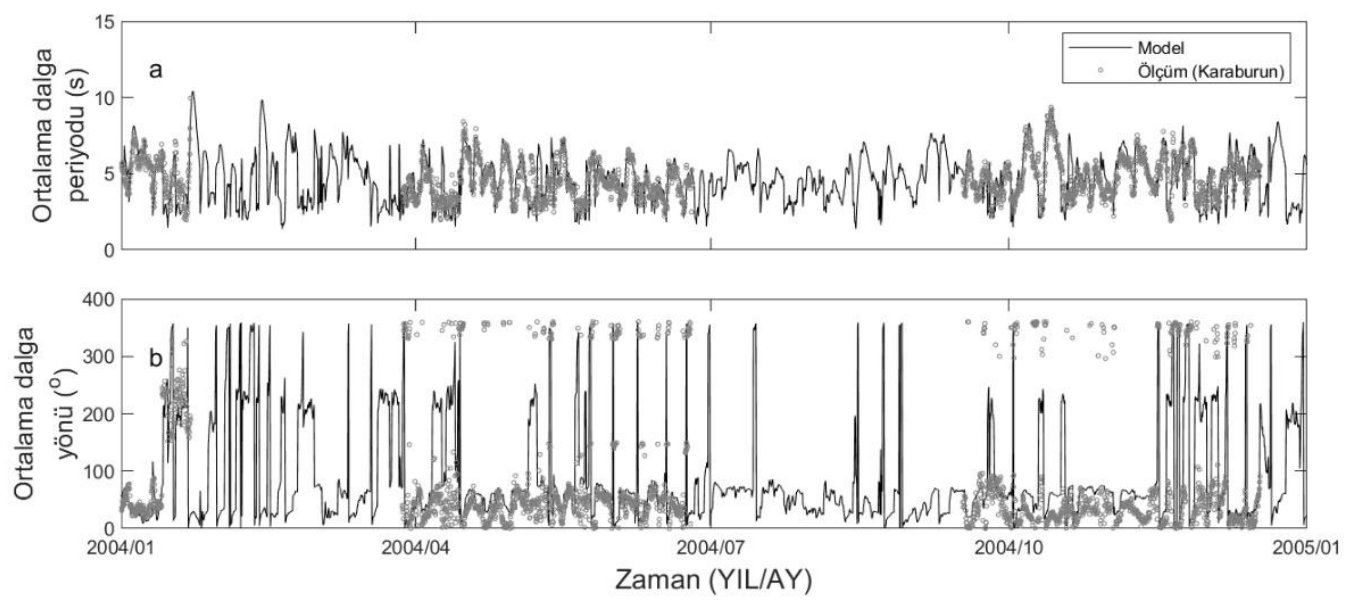

Şekil 4. Karaburun ölçüm istasyonu için WaveWatch III sayısal model sonuçları ile ölçülen (a) ortalama dalga periyodu, (b) ortalama dalga yönü zaman serilerinin karşılaştırılması

Tablo 3. Farklı istasyonlar için ölçülen ve modellenen ortalama dalga periyotlarının karșılaștırılması

Dalga periyodu

\begin{tabular}{ccccccc}
\hline İstasyon & $\begin{array}{c}\text { Ölçüm ortalama } \\
(\mathrm{s})\end{array}$ & $\begin{array}{c}\text { Model ortalama } \\
(\mathrm{s})\end{array}$ & $R$ & $R M S E(s)$ & Bias $(s)$ & $S I$ \\
\hline Karaburun & 4,64 & 4,76 & 0,79 & 0,94 & 0,18 & 0,20 \\
Filyos & 5,47 & 4,92 & 0,77 & 1,07 & $-0,52$ & 0,20 \\
Hopa & 3,90 & 4,63 & 0,68 & 1,62 & 0,91 & 0,41 \\
Sinop & 3,95 & 4,64 & 0,72 & 1,65 & 1,23 & 0,42 \\
\hline
\end{tabular}

\section{Bulgular}

\subsection{Uzun süreli rüzgar iklimi ve basınç değişimi}

Şekil 5'te 39 yıl boyunca elde edilen rüzgar hızı ve yönü saatlik verilerinin zamanla değișimi görülmektedir. Analiz süresi boyunca rüzgar hızlarının aritmetik ortalama ve standart sapma değerleri sırasıyla $5,36 \mathrm{~m} / \mathrm{s}$ ve $2,82 \mathrm{~m} / \mathrm{s}$ olmaktadır. Rüzgar hızının farklı yıllarda episodik olarak $20 \mathrm{~m} / \mathrm{s}^{\prime}$ yi așan değerlere ulaștığ görülmektedir (Şekil 5a). Bölgede etkin rüzgar yönü aralığının Kuzey (K) ile Doğu kuzeydoğu (DKD) arasında kalan yönler olduğu ve bu eğilimin 39 yll boyunca bir değişiklik göstermediği görülmektedir (Şekil $5 b$ ). $\mathrm{Bu}$ yönlerin dışında, Güney (G) ile Güneybatı (GB) yön aralı̆̆ı az da olsa etkin görülse de kuzeyli yönlerle karşılaştırıldığında diğer rüzgar yönlerinin etkisi oldukça azdır.

$\mathrm{Bu}$ çalışmada, uzun süreli değişimlerin analizinde, parametrik olmayan bir eğilim belirleme yöntemi olan en iyi uyum çizgisi (line of best fit) yöntemi kullanılmıștır. Bu yöntemde saçılmış veri noktaları arasındaki ilişkiyi en iyi ifade eden doğrunun denklemi belirlenmektedir. $\mathrm{Bu}$ doğrunun denklemi, iki ya da daha fazla bağımsız değișkenin lineer regresyon analizi sonucunda elde edilmektedir.

Rüzgar hızlarında uzun dönemli ortalama değişim, en iyi uyum çizgisinin (Sekil 6a'daki sürekli koyu siyah çizgi) eğimi ile değişimin inceleneceği süre çarpılarak elde edilmektedir. Buna göre, 39 yıl boyunca rüzgar hızlarında ortalama yaklaşı \%4 azalma olduğu görülmektedir (Şekil 6a). Her ne kadar rüzgar hızlarının ortalama değerlerinde azalma görülse de her yıl için oluşan en yüksek rüzgar hızları incelendiğinde 39 yılda ortalama yaklaşık \%12 mertebesinde artış eğilimi olduğu görülmektedir (Şekil 6b). Yıllık ortalama rüzgar yönünün ise saatlik verilerde olduğu gibi KD yönü olduğu ve rüzgar yönü için uzun dönemli bir değişimin olmadığı görülmektedir (Şekil 6c). 

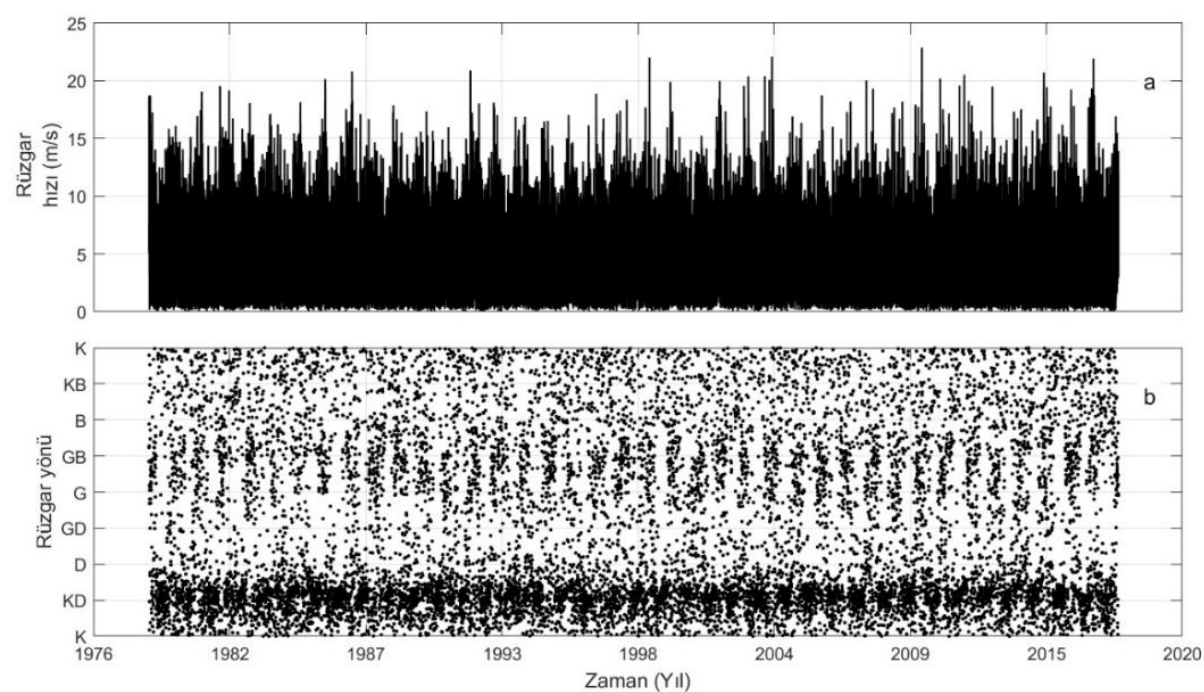

Şekil 5. 1979 ile 2017 yılları arasında Karasu'nun yaklaşık 40 km açığında (41,50 Kuzey Enlemi ve 30,50 Doğu Boylamı koordinatları) 1 saat zamansal çözünürlüklü deniz seviyesinden $10 \mathrm{~m}$ yükseklikte tanımlanmış (a) rüzgar hızı ve (b) rüzgar yönü verileri (rüzgar yönleri rüzgarın hangi yönden geldiğini göstermektedir)

İklim değişikliği göstergelerinin küresel olarak ekstrem olaylarda artışı işaret ettiği düşünüldüğünde, rüzgar hızlarının ortalama değerlerine kıyasla en yüksek değerlerinde belirgin artışlar olması bu etkinin Karasu kıyılarında da var olabileceğini göstermektedir. Bölüm 1'de de değinildiği gibi fırtınalar gibi ekstrem olayların yalnızca şiddeti değil sıklığının da iklim değişiminin etkisiyle artması beklenmektedir. Bunun için çalışma bölgesinde fırtına sürelerinin uzun dönemli değişimi de incelenmiştir.

Rüzgarın tipi, karada, denizde ve kıyıda yaptığ etkiler Beaufort rüzgar ölçeğine göre sınıflandırılmaktadır. Meteoroloji Genel Müdürlüğü [32] tarafından verilen Beaufort ölçeğine göre, 10,8 ile 13,8 m/s aralığındaki rüzgar hızları "Kuvvetli Rüzgar", 13,9 ile 17,1 $\mathrm{m} / \mathrm{s}$ aralığındaki rüzgar hızları ise "Fırtınamsı Rüzgar" olarak tanımlanmaktadır. Ülkemizde uygulanan Kıyı Yapıları Planlama ve Tasarım Teknik Esaslarında ise 13,9 ile $17,1 \mathrm{~m} / \mathrm{s}$ aralığındaki rüzgar hızları "Mutedil Fırtına" olarak tanımlanmaktadır [33]. Buna göre rüzgar hızı 13,9 m/s'nin üzerine çıktığında fırtına özelliklerini taşımaya başlamaktadır.

Bu çalışmada, fırtına başlangıcı için eşik rüzgar hızı değeri 13,9 m/s olarak alınmış ve bu değerin altına düşmeden rüzgarın esmeye devam ettiği

süre firtına süresi olarak kabul edilmiştir. Bu şekilde hesaplanan, analiz süresi boyunca her yll için gerçekleșen toplam fırtına süreleri Șekil 6d'de verilmiștir. 1979 ile 2017 yılları arasındaki verilere göre, bölgede yılda ortalama 63,3 saat fırtına şartları oluşmaktadır. Yıllık toplam fırtına sürelerindeki eğilimler incelendiğinde 2000'li yıllardan önce ortalama değerden daha az firtına oluşması eğilimi olduğu, 2000'li yıllar sonrasında firtına sürelerinde belirgin artışlar olduğu görülmektedir. Özellikle 2000 yllından önce bir yıldaki firtına süresi 100 saate hiç ulașmamıșken, 2015 ve 2016 yıllarında 140 saatin üzerinde firtına şartları oluşmuştur. Yıllık toplam firtına süresi 39 yılda ortalama yaklaşık $\% 55$ artış göstermektedir.

İklim değişikliğine bağlı olarak kıyı bölgelerinde gözlenen en önemli etkilerden biri de su seviyesi değişimleridir. Uzun süreli su seviyesi ölçümlerine ulașmak zor olsa da su seviyesi değişimlerinin önemli bir kısmının deniz üzerindeki atmosfer basıncı değișiminden kaynaklandığı bilinmektedir [34]. Barometrik basınç ile su seviyesi arasında ters bir ilişki mevcuttur. Buna göre, atmosfer basıncindaki 1 mbar (hPa)'lık artış, su seviyesinde 1,01 cm azalmaya neden olmaktadır [34]. Bundan dolayı iklim değişikliği etkisiyle meydana gelen su seviyesi artışının bir kısmı atmosfer 
DEÜ FMD 22(65), 353-368, 2020

basıncındaki belirgin azalmalar nedeniyle meydana gelmektedir [35].

Şekil 7'de 39 yıl boyunca çalışma bölgesine ait atmosfer basincl saatlik verilerinin zamanla değişimi görülmektedir. Analiz süresi boyunca atmosfer basıncı değerleri, yaklașık olarak aritmetik ortalama değeri olan 1016,27 hPa etrafında değişmektedir. Basınç verisi için standart sapma değeri 6,5 hPa olmaktadır. En iyi uyum çizgisinin eğimi kullanılarak hesaplanan atmosfer basıncı değerlerindeki 39 yıldaki ortalama azalma yaklaşık $0.27 \mathrm{hPa}$ olmaktadır. $\mathrm{Bu}$ değer su seviyesinde yaklaşık $0.27 \mathrm{~cm}$ artışa karşllık gelmektedir.

$\mathrm{Bu}$ sonuçlara göre, Karasu kıyılarındaki uzun dönemli rüzgar iklimi, fırtına şiddeti ve sıklığı gibi ekstrem olaylardaki artışı işaret eden küresel iklim değișikliği göstergeleri ile uyumlu olarak değişim göstermektedir.
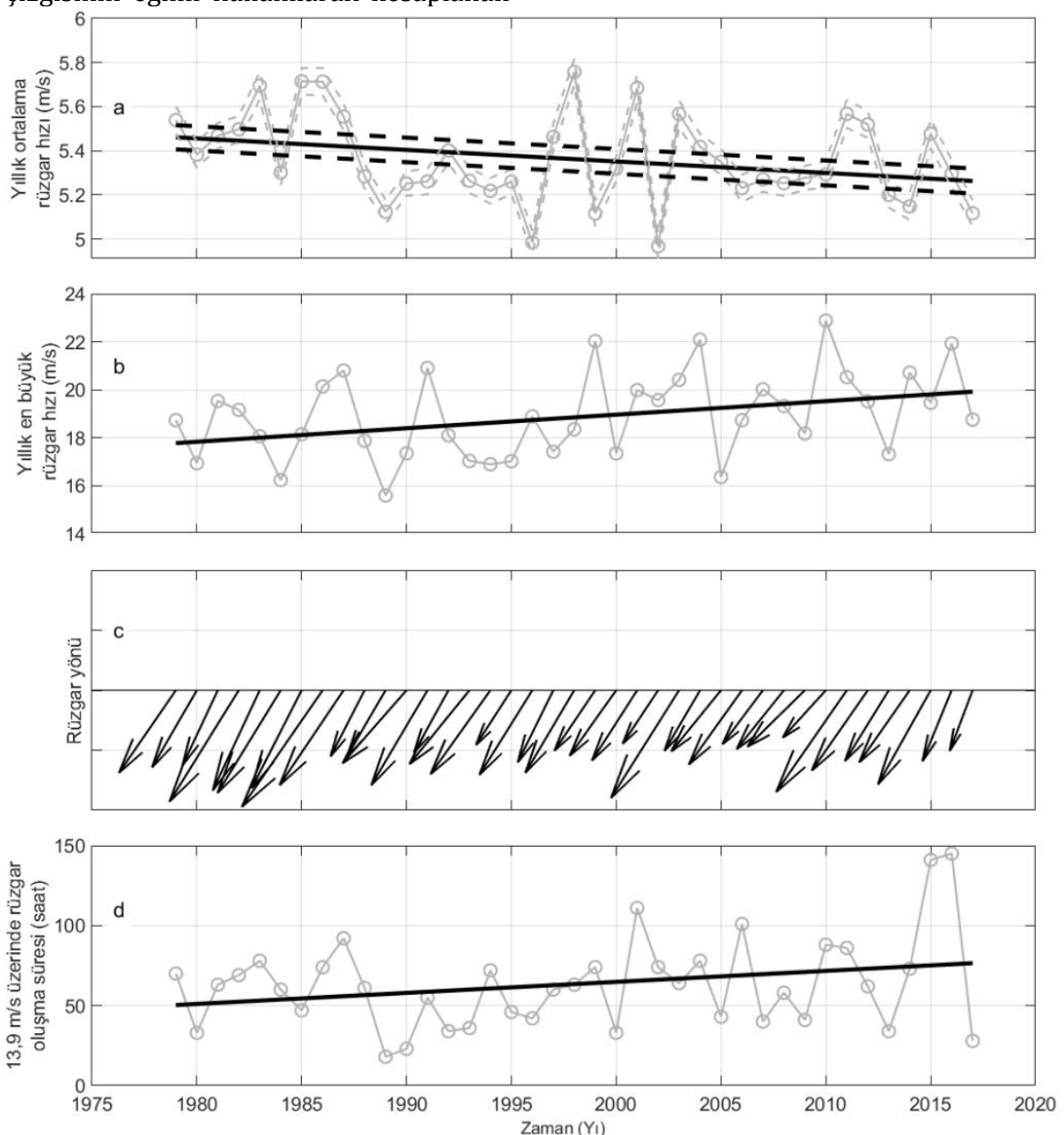

Şekil 6. Karasu'nun yaklașık 40 km açığında (41,50 Kuzey Enlemi ve 30,50 Doğu Boylamı koordinatları) (a) yıllık ortalama rüzgar hızı, (b) yıllık en büyük rüzgar hızı, (c) yıllık ortalama rüzgar yönü ve (d) yıllık fırtına süreleri. a, b ve d panellerinde bulunan koyu siyah çizgiler en iyi uyum eğilim çizgilerini, a panelinde bulunan kesikli çizgiler \%95 güven aralığını göstermektedir. 
DEÜ FMD 22(65), 353-368, 2020

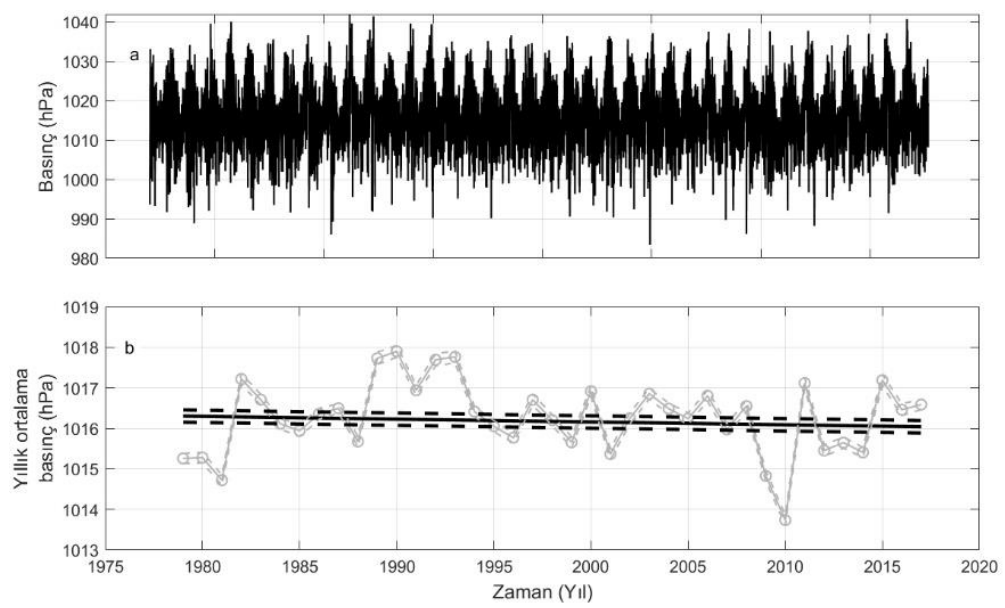

Şekil 7. Karasu'nun yaklaşık $40 \mathrm{~km}$ açığında (41,50 Kuzey Enlemi ve 30,50 Doğu Boylamı koordinatları) (a) 1 saat zamansal çözünürlüklü atmosfer basıncı ve (b) yıllık ortalama atmosfer basıncı. b panelinde bulunan koyu siyah çizgi en iyi uyum eğilim çizgisini, kesikli çizgiler \%95 güven aralığını göstermektedir.

\subsection{Uzun süreli dalga iklimi değişimi}

Enerjik bir dalga iklimine sahip bölgede, analiz edilen 31 yıl için belirgin dalga yüksekliklerinin aritmetik ortalaması $0,9 \mathrm{~m}$ ve standart sapması

0,7 m'dir (Şekil 8a). Bölgedeki ortalama dalga periyodu ise $4,9 \mathrm{~s}$ ortalamaya ve $1,5 \mathrm{~s}$ standart sapmaya sahiptir (Şekil 8b).
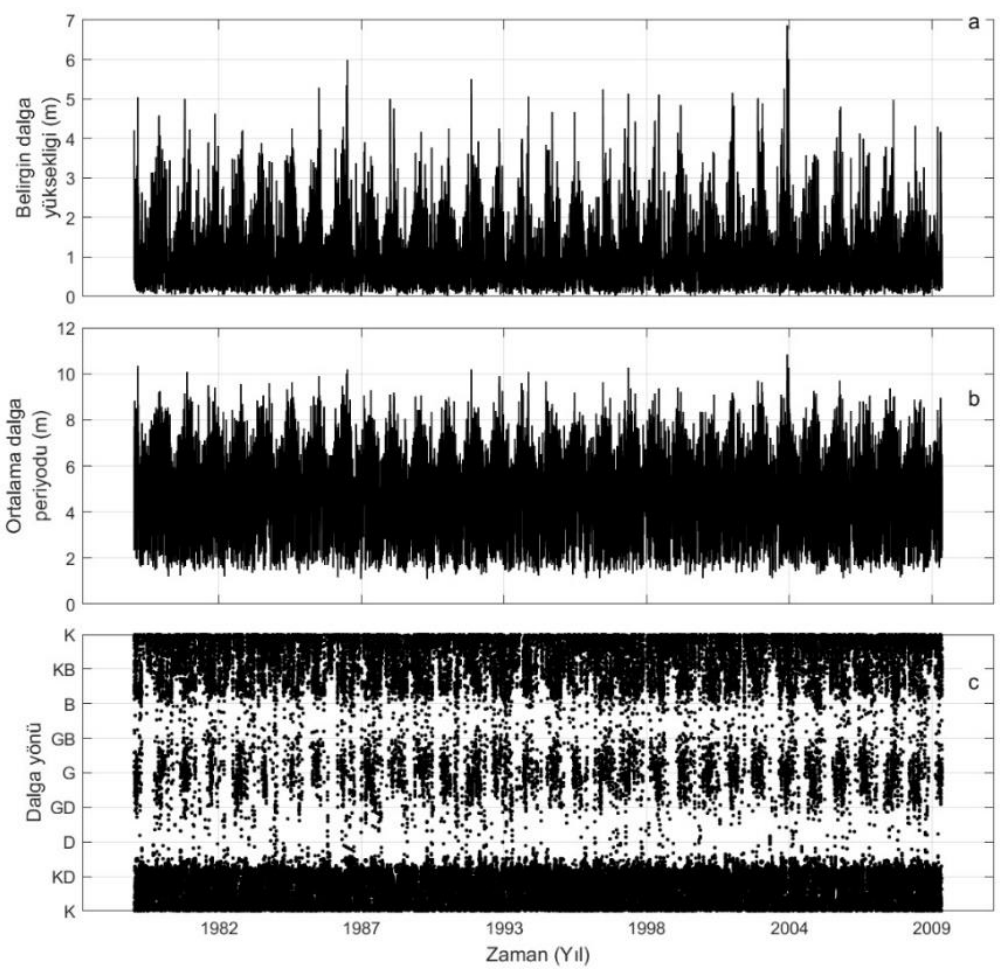

Şekil 8. Karasu'nun 23 km açı̆̆ında (41,3333 Kuzey Enlemi 30,6667o Doğu Boylamı koordinatları) WaveWatch III sayısal model sonuçları. (a) Belirgin dalga yüksekliği, (b) periyodu ve (c) yönü (yönler dalganın hangi yönden geldiğini göstermektedir) 
DEÜ FMD 22(65), 353-368, 2020

31 yıllık dalga model verisi için belirgin dalga yükseklikleri ile ortalama dalga periyodu arasında Türkiye Kıyıları için Rüzgar ve Derin Dalga Atlası [36] ile uyumlu bir ilișki elde edilmiştir (Şekil 9). Karşılaştırmada, dalga analizinde kullanılan noktanın $17 \mathrm{~km}$ güneybatısındaki $41,25^{\circ}$ Kuzey Enlemi ve 30,50 Doğu Boylamı koordinatlarında Dalga Atlası'nda mevcut olan $H_{s^{-}} T_{m}$ grafiği kullanılmıştır. Şekil 9 b'de görülen $H_{s}-T_{m}$ grafiği daha uzun süreli (31 ylllık) veri içermesinden dolayı daha fazla saçılmıș görünse de genel olarak Dalga Atlası [36]'nda verilen grafik (Şekil 9a) ile benzer davranıs göstermektedir.
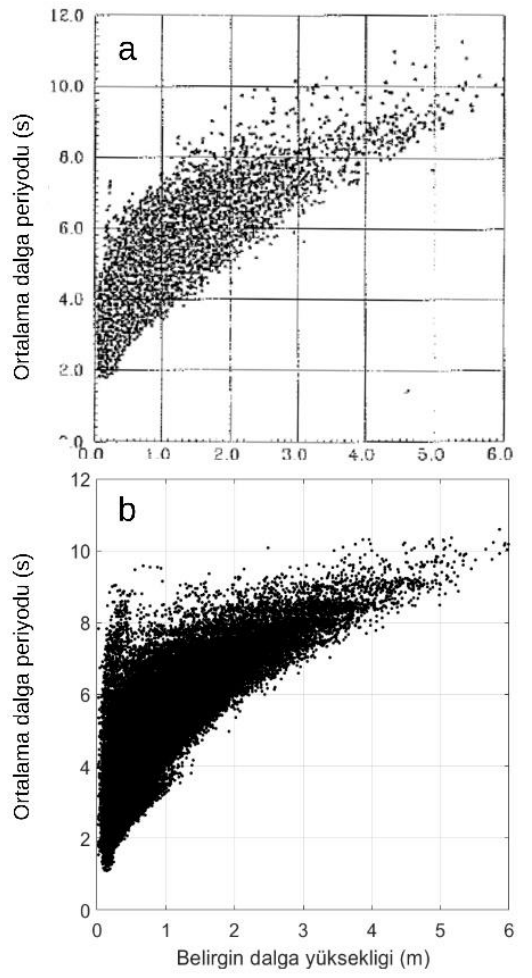

Şekil 9. Ortalama dalga periyodu ile belirgin dalga yüksekliği arasında (a) 41,25 $\mathrm{K}, 30,50^{\circ} \mathrm{D}$ koordinatlarında Türkiye Kıyıları için Rüzgar ve Derin Dalga Atlası'nda [36] verilen ilişki, (b)

41,3333 $\mathrm{K}, 30,6667^{\circ} \mathrm{D}$ koordinatlarında

WaveWatch III sayısal model sonuçları

Karasu açılklarında etkin dalga yönü aralığının Kuzey (K), Kuzey kuzeydoğu (KKD) ve Kuzeydoğu (KD) olduğu görülmektedir (Şekil 8c). Bu yönlerin dişında, Kuzeybatı (KB) ve güneyli yönler az da olsa etkin görülmektedir.
Genel olarak, kuzeyli yönlerle karşılaştırıldığında diğer dalga yönlerinin etkisi oldukça azdır (Şekil 8c).

Ylllık ortalama belirgin dalga yüksekliklerine bakıldığında 1980'li yıllarda belirgin dalga yüksekliklerinin ortalaması sonraki yıllara göre daha yüksek olsa da (Şekil 10a), en yüksek belirgin dalga yüksekliğinin (yaklaşık $\mathrm{H}_{\mathrm{s}}=7 \mathrm{~m}$ ) 2004 yılında oluştuğu görülmektedir (Şekil 10b). 31 yll boyunca yıllık ortalama belirgin dalga yüksekliklerinde yaklaşı \%11 azalma gerçekleşirken, yıllık en büyük belirgin dalga yüksekliklerinde yaklaşık \%6 artış gerçekleşmektedir (Şekil 10a ve b). Ylllık ortalama dalga periyotları, ortalama dalga yüksekliklerine benzer bir uzun dönemli değișim göstermektedir (Șekil 10a ve c). 31 yll boyunca yıllık ortalama dalga periyodunda yaklaşı $\% 4$ azalma gerçekleşmektedir ve dalga boyları kısalmaktadır (Şekil 10c). Yıllık ortalama dalga yönlerinde, rüzgar yönleri ile uyumlu olarak KKD ve KD yönleri etkin olmaktadır ve uzun dönemli belirgin bir değișim görülmemektedir (Şekil 10d).

Meteoroloji Genel Müdürlüğü tarafından verilen Beaufort ölçeğinde, bu çalıșmada firtına başlangıcı için eşik rüzgar hızı değeri olarak kabul edilen $13,9 \mathrm{~m} / \mathrm{s}$ aşıldığında denizin kabarmaya başlayacağı ve yaklaşık dalga yüksekliğinin $4 \mathrm{~m}$ olacağı belirtilmektedir [32].

Yıllara göre $4 \mathrm{~m}$ üzerinde dalga yüksekliklerinin (fırtına dalgalarının) oluşma süreleri 2000'li yıllarda belirgin olarak artmaktadır (Şekil 10e). 2000 yılına kadar 4 m'nin üzerinde belirgin dalga yüksekliği șartları yılda ortalama $\sim 25$ saat oluşmaktayken, bu değer 2000 yllından sonra yılda ortalama $\sim 35$ saate çıkmaktadır. $4 \mathrm{~m}$ üzerinde belirgin dalga yüksekliği oluşma süresinde 31 yllık analiz süresi boyunca \%100'a ulașan bir artış meydana gelmektedir. $\mathrm{Bu}$ sonuçlara göre, yıllık ortalama değerlere bakıldığında dalga yüksekliklerinde artış görülmese de (ortalama \%10 azalma), 2000 yılından sonra büyük fırtınalarının şiddetinin (ortalama \%6 artıș) ve sıklığının (ortalama $\% 100$ 'e varan artış) belirgin bir şekilde arttığı görülmektedir.

Rüzgar iklimine benzer șekilde, Karasu kıyılarındaki uzun dönemli dalga iklimi, küresel iklim değişikliği göstergeleri ile uyumlu olarak fırtına şiddeti ve sıklığı gibi ekstrem olaylardaki artışı işaret etmektedir. 
DEÜ FMD 22(65), 353-368, 2020
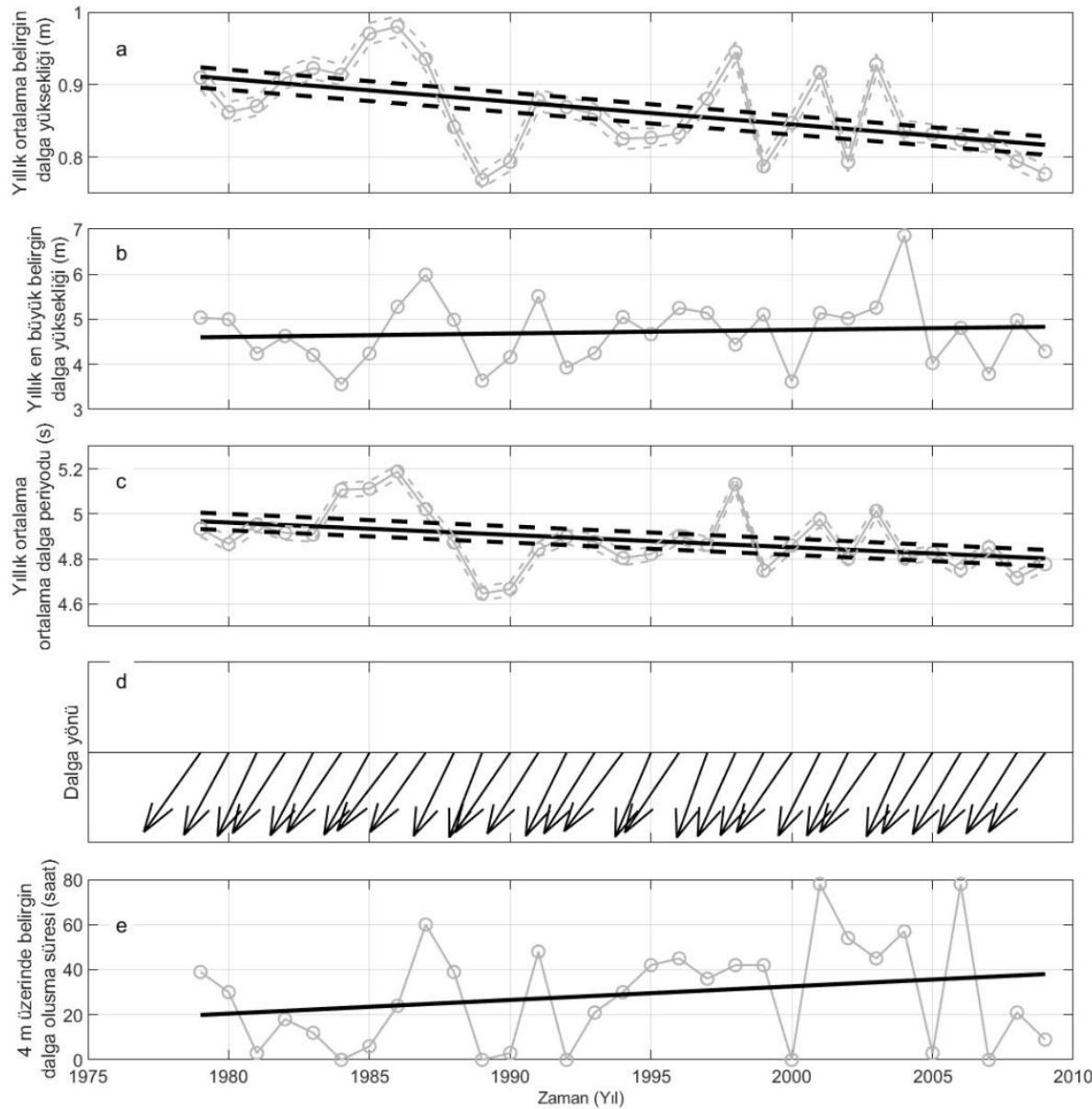

Şekil 10. Karasu'nun 23 km açığında (41,3333 Kuzey Enlemi 30,6667 Doğu Boylamı koordinatları) (a) yıllık ortalama belirgin dalga yüksekliği, (b) yıllık oluşan en büyük belirgin dalga yüksekliği, (c) yıllık ortalama dalga periyodu, (d) yıllık ortalama dalga yönü ve (e) belirgin dalga yüksekliği 4 m'nin üzerinde dalgaların oluşma süreleri. a, b ve c panellerinde bulunan koyu siyah

çizgiler en iyi uyum eğilim çizgilerini, a ve c panellerinde bulunan kesikli çizgiler \%95 güven aralıklarını göstermektedir.

\section{Tartışma ve Sonuç}

Kıyı sistemlerinin artan firtına șiddetleri ve süreleri, yükselen su seviyesi, artan sıcaklıklar ve yağışlardaki değişimlerden büyük ölçüde etkilenmesi beklenmektedir. Akarsu deltaları çok çeşitli habitata sahip doğal sistemlerin ve insan yaşamının (evler, turizm bölgeleri, tarım, su ürünleri yetiştirme alanları, endüstri ve taşımacılık gibi) bir araya geldiği bölgelerdir. Küçük kıyı eğimi ile karakterize edilen düșük rakımlı kıyı alanları olan haliç ve deltalar, iklim değişikliğinin bir sonucu olarak gelecekte görülebilecek etkilere karşı yüksek derecede kırılgan bölgelerdir. Bu gibi bölgelerde iklim değișikliğine bağlı olarak rüzgar ve dalga özellikleri, deniz suyu seviyesi ve sıcaklıkları, akarsu debileri gibi fiziksel süreçlerdeki değişimlerin anlaşılması önemlidir.

Güneybatı Karadeniz'de Karasu kıyısında yer alan ve enerjik bir dalga-akıntı iklimine sahip, morfolojik açıdan dinamik, insan kaynaklı değişimlerin kıyı kesimini önemli ölçüde etkilediği, ekolojik, turistik ve ticari açıdan önemli alanları etki bölgesi içinde barındıran Sakarya Nehri Deltası, iklim değişikliği süreçlerinden etkilenmesi olası bir bölge olduğundan bu çalışmada incelenmiştir. 


\section{DEÜ FMD 22(65), 353-368, 2020}

$\mathrm{Bu}$ çalıșmada, bölgenin rüzgar ve dalga iklimindeki uzun dönemli değişimlere yoğunlaşılmış ve bu etkilerin önemi araştırılmıștır. Analizlerde 1979 yılından, 2017 yılına kadar modellenmiş rüzgar ve 2009 yılına kadar modellenmiş dalga verileri kullanılmıștır. Analiz süreleri boyunca yıllık ortalama rüzgar hızlarında ve belirgin dalga yüksekliklerinde azalma (sırasıyla $\sim \% 4$ ve $\sim 11$ ) olduğu görülmüştür. Yıllara göre ortalama değerlerde azalma olmasına rağmen analiz süresi boyunca oluşan en ekstrem rüzgar ve dalga durumları 2000 yılından sonraki sürede gerçekleșmiştir. Yıllık en büyük rüzgar hızı ve belirgin dalga yüksekliğinde ise sırasıyla yaklaşık $\% 12$ ve $\% 6$ artış eğilimi olmaktadır.

Rüzgar ve dalga koşullarında firtına şartlarının olușma süreleri analiz dönemi boyunca iki kata ulaşan sürelere çlkmaktadır. Atmosfer basıncında 39 yılda ortalama yaklașık $0.27 \mathrm{hPa}$ azalma olmaktadır. $\mathrm{Bu}$ değer basınç değişiminden dolayı analiz süresi boyunca yaklaşık $0.27 \mathrm{~cm}$ su seviyesi artışını işaret etmektedir.

Hem rüzgar hem de dalga iklimindeki uzun süreli değişimler, günümüze yaklaştıkça ekstrem olayların şiddetlerinde ve sürelerinde belirgin artışlar olduğunu göstermektedir. Bu değişimler, dalga ikliminde görece az da olsa daha belirgin olmaktadır. Çalışma bölgesinin rüzgar ve dalga ikliminde uzun dönemde ortalama değerlerden ziyade ekstrem olayların şiddetinde ve sıklığında artışların görülmesi küresel iklim değișikliği etkilerinin belirtileri ile uyum göstermektedir.

Bu çalışmada kullanılan dalga verileri Kuzeybatı Atlantik, Hawaii ve Kuzeydoğu Pasifik basenlerindeki dalga verileri ile kalibre edilen küresel WaveWatch III spektral modeli sonuçlarının bulunduğu NOAA CFSRR veri tabanından elde edilmiștir. $\mathrm{Bu}$ veriler tüm dünyada operasyonel olarak kullanılmaktadır. Model verileri, Karadeniz'de farklı konumlarda bulunan ölçümler ile karşılaştırılarak Karadeniz için doğruluğu gösterilmiştir.

$\mathrm{Bu}$ çalışmanın devamı niteliğinde gerçekleştirilecek gelecekteki çalışmalarda rüzgar ve dalga iklimindeki değișimlere ilave olarak su seviyesi, yağış rejimi gibi diğer iklim değişikliği göstergelerindeki uzun dönemli değişimler de dikkate alınarak katı madde dinamiğinde ve kıyı morfolojisinde gelecekte oluşabilecek değişimler ile bu değişimlerin kıyı şeridi üzerindeki olası etkileri incelenmelidir. Bu tür çalışmalar hem çalışma bölgesi hem de nehir, kıyı ve denizin etkileşimde olduğu benzer bölgelerde iklim değişikliğine bağlı oluşabilecek risklerin ve bu risklere karşı alınması gereken önlemlerin belirlenmesinde rol oynayacaktır.

\section{Teşekkür}

$\mathrm{Bu}$ çalıșma, Türkiye Bilimsel ve Teknolojik Araștırma Kurumu (TÜBITAK) tarafından 1001 Bilimsel ve Teknolojik Araştırma Projelerini Destekleme Programı kapsamında 117Y333 nolu proje ile desteklenmiștir. Rüzgar ve basınç alan verileri ile WaveWatch III spektral modeli sonuçlarının paylaşımından dolayı NOAA (National Oceanic Atmospheric Administration)'ya, bu verilerin teminindeki yardımlarından dolayı Doç. Dr. Ilgar Şafak ve Araş. Gör. Fulya İşlek'e, Karaburun dalga ölçüm verileri için Prof. Dr. Yalçın Yüksel'e, NATO TU-WAVES projesi kapsamında ölçülen Hopa ve Sinop şamandıra verileri için Prof. Dr. Erdal Özhan'a, Filyos dalga verileri için Altyapı Yatırımları Genel Müdürlüğü’ne ve makaleye görüșleri ile katkı sağlayan hakemlere teşekkür ederim.

\section{Kaynakça}

[1] Allen, M. R., Ingram, W. J. 2002. Constraints on future changes in climate and the hydrologic cycle. Nature, 419 (6903), 224-232, doi: 10.1038/ nature01092.

[2] IPCC 2007. Climate Change 2007: the physical science basis. Contribution of Working Group I to the Fourth Assessment Report of the Intergovernmental Panel on Climate Change. Editörler: Solomon, S., Qin, D., Manning, M., Chen, Z., Marquis, M., Averyt, K.B., Tignor, M., Miller, H.L. Cambridge University Press, Cambridge, U.K. 996 pp.

[3] Meehl, G.A., Stocker, T.F., Collins, W.D., Friedlingstein, P., Gaye, A.T., Gregory, J.M., Kitoh, A., Knutti, R., Murphy, J.M., Noda, A., Raper, S.C.B., Watterson, I.G., Weaver, A.J., Zhao, Z.-C. 2007. Global climate projections. Climate Change 2007: The Physical Science Basis, Contribution of Working Group I to the Fourth Assessment Report of the Intergovernmental Panel on Climate Change. Editörler: Solomon, S., Qin, D., Manning, M., Chen, Z., Marquis, M., Averyt, K.B., Tignor, M., Miller, H.L. pp. 749-845, Cambridge Univ. Press, Cambridge, United Kingdom and New York, NY, USA.

[4] Allan, R. P., Soden, B. J. 2008. Atmospheric warming and the amplification of precipitation extremes, Science, 321(5895), 1481-1484, doi:10.1126/science.1160787

[5] Lima, F.P., Wethey, D.S. 2012. Three decades of highresolution coastal sea surface temperatures reveal more than warming, Nature Communications, 3, 704, doi: $10.1038 /$ ncomms1713.

[6] Wong, P.P., Losada, I.J., Gattuso, J.-P., Hinkel, J., Khattabi, A., McInnes, K.L., Saito, Y., Sallenger, A. 2014. Coastal systems and low-lying areas. Climate Change 2014: Impacts, Adaptation, and Vulnerability. Part A: Global and Sectoral Aspects. Contribution of Working Group II to the Fifth Assessment Report of the Intergovernmental Panel on Climate Change. Editörler: Field, C.B., V.R. Barros, D.J. Dokken, K.J. Mach, M.D. Mastrandrea, T.E. Bilir, M. 


\section{DEÜ FMD 22(65), 353-368, 2020}

Chatterjee, K.L. Ebi, Y.O. Estrada, R.C. Genova, B. Girma, E.S. Kissel, A.N. Levy, S. MacCracken, P.R. Mastrandrea, and L.L. White. Cambridge University Press, Cambridge, United Kingdom and New York, NY, USA, pp. 361-409.

[7] Nicholls, R.J., 2010. Impacts of and responses to sealevel rise. Understanding Sea-level Rise and Variability. Editörler: Church, J.A., Woodworth, P.L. Aarup, T., Wilson W.S. Wiley-Blackwell, Chichester, UK and Hoboken, NJ, USA, pp. 17-51.

[8] McLeod, E., Poulter, B., Hinkel, J., Reyes, E., Salm, R. 2010. Sea-level rise impact models and environmental conservation: a review of models and their applications, Ocean and Coastal Management, 53(9), 507-517.

[9] Shirkhani, H., Seidou, O., Mohammadian, A., Qiblawey, H. 2015. Projection of Significant Wave Height in a Coastal Area under RCPs Climate Change Scenarios, Nat. Hazards Rev., 10.1061/(ASCE)NH.1527-6996.0000192, 04015016.

[10] Alpar, B., 2009. Vulnerability of Turkish coasts to accelerated Sea level rise, Geomorphology, 107:5863.

[11] Ericson, J.P., Vorosmarty, C.J., Dingman, S.L., Ward, L.G., Meybeck, M. 2006. Effective sea-level rise and deltas: causes of change and human dimension implications, Global Planet Change, 50, 63-82.

[12] Foufoula-Georgiou, E., Syvitski, J., Paola, C., Hoanh, C.T., Tuong, P., Vörösmarty, C., Kremer, H., Brondizio, E., Saito, Y., Twilley, R. 2011. International Year of Deltas 2013: a proposal, Eos, Transactions of American Geophysical Union, 92, 340-341.

[13] Tsimplis, M.N., Shaw, A. 2010. Seasonal sea level extremes in the Mediterranean Sea and at the Atlantic European coasts, Nat. Hazards Earth Syst. Sci. 10, 1457-1475.

[14] Sanchez-Arcilla, A., Jimenez, J.A., Valdemoro, H.I., Gracia, V. 1998. Implications of climatic change on Spanish Mediterranean low-lying coasts: the Ebro Delta case, Journal of Coastal Research, 24, 306-316.

[15] Simeoni, U., Corbau, C. 2009. A review of the Delta Po evolution (Italy) related to climatic changes and human impacts, Geomorphology, 107, 64-71.

[16] Nageswara Rao, K., Subraelu, P., Naga Kumar, K.Ch.V. Demudu, G., Hema Malini, B., Rajawat, A.S., Ajai, 2010 Impacts of sediment retention by dams on delta shoreline recession: evidences from the Krishna and Godavari deltas, India, Earth Surface Processes and Landforms, 35, 817-827.

[17] Yang, S.L., Milliman, J.D., Li, P., Xu, K. 2011. 50,000 dams later: erosion of the Yangtze River and its delta Global and Planetary Change, 75, 14-20.

[18] Chu, Z.X., Sun, X.G., Zhai, S.K., Xu, K.H. 1996. Changing pattern of accretion/ erosion of the modern Yellow River (Huanghe) subaerial delta, China: based on remote sensing images, Marine Geology, 227, 13-30.

[19] Barras, J.A., Bernier, J.C., Morton, R.A. 2008. Land Area Change in Coastal Louisiana: A Multidecadal Perspective (from 1956 to 2006). Pamphlet to accompany U.S. Geological Survey Scientific Investigations Map 3019, scale 1:250,000, USGS, Reston, VA, USA, $14 \mathrm{pp}$.

[20] Syvitski, J.P.M., Kettner, A.J., Overeem, I., Hutton, E.W.H., Hannon, M.T., Brakenridge, G.R., Day, J.,
Vörösmarty, C., Saito, Y., Giosan, L., Nicholls, R.J. 2009. Sinking deltas due to human activities, Nature Geoscience, 2, 681-686.

[21] Katsman, C.A., Beersma, J.J., van den Brink, H.W., Church, J.A., Hazeleger, W., Kopp, R.E., Kroon, D., Kwadijk, J., Lammersen, R., Lowe, J., Oppenheimer, M., Plag, H.P., Ridley, J., von Storch, H., Vaughan, D.G., Vellinga, P., Vermeersen, L.L.A., van de Wal, R.S.W., Weisse, R. 2011. Exploring high-end scenarios for local sea level rise to develop flood protection strategies for a low-lying delta - the Netherlands as an example, Climate Change, 109, 617-645

[22] Elektrik İşleri Etüd İdaresi Genel Müdürlüğü, Hidrolik Etüdler İdaresi Bșk. (2011). http://www.eie.gov.tr/turkce/YEK/HES/hidroloji/ 12sakarya.html, Erişim tarihi: 14 Eylül 2011.

[23] Munsuz, N., Ünver, İ, Çaycı G. 1999. Türkiye Suları. Ankara Üniversitesi, Ziraat Fakültesi, Yayın no: 1505, Ders Kitabı: 459. Ankara.

[24] TMMOB (Türk Mühendis ve Mimar Odaları Birliği) 2012. Karasu Kıyı Alanı Kıyı Daralması Raporu. Mattek Basım Yayın, Ankara.

[25] Yuksel, Y., Tan, R. I., Ayat, B., Guner, H. A., Aydogan, B., Seker, D. 2013. A Coastal Management Case Study in Karasu at Black Sea Region, Proceedings of the Twenty-Third (2013) International Offshore and Polar Engineering (ISOPE).

[26] Saha, S., et al. 2011, updated monthly. NCEP Climate Forecast System Version 2 (CFSv2) Selected Hourly Time-Series Products. Research Data Archive at the National Center for Atmospheric Research, Computational and Information Systems Laboratory. https://doi.org/10.5065/D6N877VB. Erişim Tarihi: 5 Ekim 2018.

[27] Chawla, A., Spindler, D.M. and Tolman, H.L. 2012. Validation of a thirty year wave hindcast using the Climate Forecast System Reanalysis winds. Ocean Modelling. doi:10.1016/j.ocemod.2012.07.005.

[28] Tolman, H.L. 2009. User manual and system documentation of WAVEWATCH III TM version 3.14. Tech. Note 276, NOAA/NWS/NCEP/MMAB.

[29] Arı Güner, H. A., Yüksel, Y., Özkan Çevik, E. 2013. Estimation of Wave Parameters Based on Nearshore Wind-Wave Correlations, Ocean Engineering, 63, 5262.

[30] Bilyay, E., Ozbahceci, B. O., Yalcıner, A. C. 2011. Extreme Waves at Filyos, Southern Black Sea, Natural Hazards and Earth System Science, 11(3), 659-666.

[31] Özhan, E., Abdalla, S. 1999. Wind and wave Climotology of Turkish Coasts and The Black Sea: An Overview of the NATO TU_WAVES Project, MEDCOAST Conference on Wind and Wave Climate of the Mediterranean and the Black Sea, AntalyaTurkey, 1-20.

[32] Deniz, A. (2008). Beaufort (Bofor) Rüzgar Iskalası. Meteoroloji Genel Müdürlüğü. https://www.mgm.gov.tr/FILES/genel/makale/bea ufort.pdf

[33] AYGM (2016). Kıyı Yapıları - Planlama ve Tasarım Teknik Esasları, T.C. Ulaştırma, Haberleşme ve Denizcilik Bakanlığı Altyapı Yatırımları Genel Müdürlüğü. 
DEÜ FMD 22(65), 353-368, 2020

[34] Brown, W., Munk, W., Snodgrass, F., Mofjeld, H., Zetler, B. 1975. Mode bottom experiment, J. Phys. Oceanogr. 5, 75-85.

[35] Smith, M.S., 2016. Contributions of recent barometric pressure trends to rates of sea level rise in southeastern Massachusetts (USA), Regional Studies in Marine Science, 8, 41-50.

[36] Özhan, E., Abdallah, S. 1999. Türkiye kıyıları için Rüzgar ve Derin Deniz Dalga Atlası, ODTÜ. 